\title{
SWI/SNF-Related Matrix-Associated Actin- Dependent Regulator of Chromatin Subfamily D Member 3
}

National Cancer Institute

\section{Source}

National Cancer Institute. SWI/SNF-Related Matrix-Associated Actin-Dependent

Regulator of Chromatin Subfamily D Member 3. NCI Thesaurus. Code C19844.

SWI/SNF-related matrix-associated actin-dependent regulator of chromatin subfamily $D$ member 3 (483 aa, $25 \mathrm{kDa}$ ) is encoded by the human SMARCD3 gene. This protein plays a role in nucleosome remodeling, neuronal development and transcriptional regulation. 